\title{
Conceptualizing capitalist transformations: Marx's relevance for higher education research $^{1}$ \\ Krystian Szadkowski², Jakub Krzeski
}

\begin{abstract}
This article opens a space for dialogue between Marxism and the field of higher education research. First, it demonstrates to what extent Marx is present in the theoretical and methodological discussions within the field and it examines the reasons behind his absence, i.e., the development of two perspectives regarding capitalist transformations, namely academic capitalism and exceptionalism. Second, it introduces Marx's method of critique, conceived as the integrity of three different analytical moments and it further explicates how those moments can be translated into the general research program. It does so in reference to a) ontological assumptions; b) sector's political economy; c) students and academic protests; d) ideas about the alternative. Finally, it uses those four areas to reflect on the key differences between Marx's critique and the two perspectives discussed. By doing so it opens up paths for further dialogue between Marxism and higher education research.
\end{abstract}

Keywords: Karl Marx, critique, method, exceptionalism, academic capitalism

\footnotetext{
${ }^{1}$ This is a manuscript submitted to Critique: Journal of Socialist Theory

${ }^{2}$ Contact address: krysszad@amu.edu.pl
} 


\section{Introduction}

Introducing new theoretical and methodological perspectives to the field of higher education research (HER) that suffers from a severe undertheoretization (Slaughter 2001; Tight 2003, 2004, 2015; Ashwin 2012) is not an easy task. The obstacles are both the structural problems of the field itself (Teichler 1996; 2015), its multidisciplinarity, the domination of practical orientation and the low degree of institutionalization of research, programs and fields of study, its undefined boundaries, as well as the problem of its genesis, i.e. response to the growing needs of governments to control the process of massification of the sector. The field of HER has very little achievements in the area of generating its own theories (Tight 2015: 277), and participants in discussions conducted within it are usually recruited from various fully developed disciplines (Teichler 2015). The discussion within the field is rather conservative and is dominated by „,cohesive" researchers with more conservative agendas, while there are no favourable conditions for more open and innovative ,trailblaizing” researchers (Santos \& Horta 2018). Although, as pointed out by Tight (2018), HER has entered the stage of synthesis and meta-reflection, i.e. it has achieved the ability to order its problems (e.g. Horta \& Jung 2014) and identify areas where further development is possible (Daenekindt \& Huisman 2020), a persistent problem that hinders its theoretical development is the relatively small share of purely conceptual works (Tight 2013), as well as the fact that the works published in the main communication channels of the field still largely refer to theoretical assumptions only implicitly (Tight 2014). Moreover, if explicit conceptual reflection is developed within HER at all, it is the case in more general disciplinary journals - e.g. sociological or organization studies (Tight 2004; Clegg 2012: 668; Ashwin 2012: 950). The situation is not helped by the fact that from their inception, HER developed mainly in two poorly connected areas: policy research and teaching and learning (MacFarlane 2012; Clegg 2012; Horta \& Jung 2014), neither of which has a natural tendency to theorize. This fundamental thematic split, coupled with the thematic fragmentation developing on its margins (MacFarlane 2012), is not only deepening but threatens to progressively disintegrate the field itself (Daenekindt \& Huisman 2020). We argue, however, that despite all the problems mentioned above HER has something to offer to other research perspectives and a potential to contribute modestly to their theoretical development. By this we mean not only the possibility of using the results of research by theories developed in relation with other social areas, but the entering into some sort of a dialogue. In this text, we attempt to present the relevance of Marx's method of critique for HER (see Szadkowski \& Krzeski 2019a, forthcoming), assuming that it allows for a productive dialogue in which both sides can prosper.

Although Marxism developed complex theoretical tools to analyse various areas of social and economic life, it has only occasionally dealt with higher education. Marx's remarks on forprofit educational institutions or the role of knowledge in the development of capitalism (Marx 1982; see Szadkowski 2016; Szadkowski 2019a) did not translate into Marxist reflection on the sector. Nevertheless, along with the works of J. D. Bernal (1939) or Boris Hessen (1931/2009), a Marxist reflection on the material organization of science developed. Moreover, with such Marxists as Antonio Gramsci and his concept of hegemony, we can speak of the indirect influence of Marxism on the analysis of higher education and its role in capitalism. In turn, the work of such authors as Samuel Bowles and Herbert Gintis (1976) paved the way for a Marxist analysis of higher education in the era of massification, while Louis Althusser (1971) devoted much attention to the relationship between higher education institutions and the sphere of ideology and its reproduction. More recently, Glenn Rikowski (1997) developed the theory of the role of higher education in the reproduction of the labour force under capitalism. On the other hand, the works of Harry Cleaver (2004) and David Harvie (2005) build the grounds for 
understanding learning as a form of work. These contributions, however, were characterized by a lack of systematic approach to the sector as a whole, and the lack of a reflection on its specificity. Only in the last twenty years, we have seen a growing interest in the issues of science and higher education, academic labour and student mobilizations among authors who arise directly from the Marxist tradition (see. Harney \& Moten 1999; Gulli 2009; Roggero 2011; Winn 2015; Neary 2016; Szadkowski 2016; 2019a; 2019b; Hall 2018; Arboledas-Lerida 2020; Rikap \& Harari-Karmedoc 2021; Welsh 2020; 2021). However, they rarely relied on the findings of mainstream HER or were published in HER core outlets.

Contrary to the weak link between Marxism and HER, this article argues that some form of a dialogue between the two perspectives is possible and it further establishes the grounds on which it can occur. The argument proceeds as follows. First, a short bibliometric study on the presence (or absence, as it will be shown) of reference to Marx in HER is presented. Next, the reasons behind this absence are discussed. The two dominant types of reflections on capitalist transformations in the sector, competing with Marxism, are highlighted: exceptionalism, i.e. assumptions about the uniqueness of the organization of the sector and the autonomy of its logic, and thus the impossibility of introducing strictly capitalist relations of production (Marignson 2013), and academic capitalism, that sees the changes in terms of the expansion of the market and quasi-market mechanisms (Slaughter \& Rhoades 2004). In turn, the next part captures the components of Marx's critique. Referring to the previous findings, the next part answers the question: what can be theoretically gained for HER by entering into dialogue with Marxism? From this, a discussion section follows that puts these findings into a dialogue with the limitations of two dominant theoretical positions in HER. It not only outlines possibilities for overcoming these limitations through dialogue with Marxism but also suggesting what Marxism can gain from an encounter with HER.

\section{Higher education research and Marx - a bibliometric view}

If Marxist reflection dealt little with higher education, it penetrated even less into HER. To illustrate the scale of this absence, we have made a bibliometric analysis. We searched the Scopus database and articles from fifteen leading HER journals (for their entire indexation periods) for references to „Marx”. We cleaned up the preliminary results by reviewing the references of each of the articles found to leave only those referencing the work of Karl Marx (41 in total). Then we read the articles and indicated those that actually use Marx's theories to develop their theoretical perspectives (11), and not only mention him superficially. The results broken down by journals are presented in Table 1.

\begin{tabular}{|l|l|r|r|}
\hline Name & Period & Number of articles & Use \\
\hline Studies in Higher Education; & 1976 - Present & 3 \\
\hline The Journal of Higher Education; & $1994 ; 1996$ - Present & 3 \\
\hline Review of Higher Education; & $1996-2020$ & 1 \\
\hline Research in Higher Education; & 1973 - Present & 2 \\
\hline Higher Education Research \& Development; & 1982 - 1995; 1997; 1999 - Pres & 3 \\
\hline Higher Education & 1972 - Present & 3 \\
\hline Assessment \& Evaluation in Higher Education; & 1981 - Present & \\
\hline Higher Education Policy; & $1992 ; 1995$ - Present & 3 \\
\hline Higher Education Quarterly; & 1947 - Present & \\
\hline Journal of Higher Education Policy and Management; & 2003 - Present & \\
\hline Teaching in Higher Education; & 2005 - Present & \\
\hline European Journal of Higher Education & 2011 - Present & 1 \\
\hline Tertiary Education and Management & 1995 - Present & 7 \\
\hline Quality in Higher Education & 1995 - Present & 1 \\
\hline Higher Education in Europe & 1976 - 1995; 2005 - 2009 & \\
\hline & $5 u m$ & \\
\hline
\end{tabular}


Table 1. Presence of references to Marx's works in main HER outlets. Data source: Scopus. Authors' own elaboration.

The references seem to have a marginal position. Even though in general less theory work takes place in HER compared to other fields, 11 articles using Marx's theory to analyse the problems of higher education seem insignificant. It is noteworthy that all articles using Marx's oeuvre published in HER journals come from 2009-2020. Moreover, unlike typical articles in this field (Tight 2014, Ashwin 2012), most of them are conceptual, using inspiration from Marxist theory to intervene in existing discussions in HER. This, however, points to the untapped potential that could arise from this rapprochement.

A more in-depth review of selected articles shows the areas of use of Marx's theory in HER. First, it is used to build holistic theories for reinterpreting the broad concepts used in the field. Thus, Jessop (2017) reinterprets the concept of academic capitalism with the help of a Marxinspired cultural political economy, Walker (2009) uses Marx's reflection on time in capitalism to formulate another dimension of globalization and its impact on the sector. Secondly, we can point to a group of articles critically analysing the concepts of academic identity, one of the main topics in HER (Tight 2014, 2015). On the one hand, starting from Marx's political economy and his negative critique of labour (Neary \& Winn 2017; Collins, Glover \& Myers 2020), on the other hand, from moral political economy and more humanist perspectives (Sutton 2014; 2017). Thirdly, Marx's theory is used as a reference point in reflection on the transformation of the sphere of education, its commodification and the accompanying discourses of excellence (Saunders \& Blanco Ramirez 2017), in developing critical methods of educating students (Fox \& O'Maley 2017), or as one from positions in discussions about neoliberalism in higher education (Grealy \& Laurie 2017). Fourthly, we have articles using Marxian ideas to methodologically ground their own research. Trowler (2015) uses Marx's concept of „chaotic conceptions" and Fraser (2009) refers to Marx's methodological considerations to feed his critical approach on urban pedagogy. The fact that as many as 4 out of 11 using articles appeared in Teaching in Higher Education is not surprising. Marx's presence in education and pedagogy has a long tradition and his works theoretically feed into research in these areas (including higher education), however, they are published in general educational journals.

For some reason, however, Marx's works are not successfully used in developing theoretical assumptions in HER. If you look at „The International Encyclopaedia of Higher Education Systems and Institutions", references to the works of the author of Das Kapital are found in only three entries: „Philosophical Perspectives”, „Sociological Perspectives” and „Leadership in Higher Education, Concepts and Theories", two of which was co-written by Ilkka Kaupinnen, one of the representatives of the academic capitalism tendency. We encounter a similar invisibility of Marx in the case of one of the most important book series on theory in HER, „Theory \& Methods in Higher Education”. There, too, references to Marx are almost absent. A symptomatic example is the chapter by Cecilia Rikap (2017) published in this series, although the researcher refers to Marxist works, she only invokes Marx's theories implicitly, as if the work had been subject to self-censorship (in other works on a very similar topics, the researcher uses direct references to Marx, see. Rikap \& Kermadoc 2020). Perhaps there might be an unspoken belief that there is no room for developing Marx's theory in HER? A similar doubt would be raised by the fact that although key researchers in the field have productively engaged in developing Marxist theory (see. Marginson 1998, 2004), these were incidental cases, and usually made in journals of key importance to other disciplines (in the cited case - economics and education). It seems, however, that the assumption about deliberately displacing Marx's theory from the HER would be going too far. 
One could say: Marx is outdated and therefore not cited in HER, but authors of Marxist provenance are widely present in the reflection of higher education researchers. Therefore, we have supplemented our analysis by similar searchers for citations to the second (Antonio Gramsci - 37), the third (Luis Althusser - 19, Theodore W. Adorno - 22) and the fourth (Immanuel Wallerstein - 37) generation of Marxist thinkers from various national traditions (Italian, French, German and Anglosaxon), whose concepts are extensively used in general social sciences and humanities. Their work seems much more relevant for research into higher education, as it was focused (excluding Wallerstein) on the changes in and the structure of ideology - not in the sphere of production. The number of articles citing the works by these authors is even smaller than those by Marx (41) himself. Table 2 presents our findings.

\begin{tabular}{|c|c|c|c|c|c|}
\hline & Period & Gramsci & Wallerstein & Allthusser & Adorno \\
\hline Studies in Higher Education; & 1976 - Present & 5 & 5 & 3 & 3 \\
\hline The Journal of Higher Education; & $1994 ; 1996$ - Present & 5 & 1 & 1 & 1 \\
\hline Review of Higher Education; & $1996-2020$ & 2 & 0 & 3 & 0 \\
\hline Research in Higher Education; & 1973 - Present & 0 & 0 & 0 & 3 \\
\hline Higher Education Research \& Development; & $1982-1995 ; 1997 ; 1999$ - Present & 0 & 1 & 1 & 2 \\
\hline Higher Education & 1972 - Present & 8 & 12 & 3 & 3 \\
\hline Assessment \& Evaluation in Higher Education; & 1981 - Present & 2 & 0 & 1 & 1 \\
\hline Higher Education Policy; & $1992 ; 1995$ - Present & 1 & 3 & 2 & 1 \\
\hline Higher Education Quarterly; & 1947 - Present & 1 & 1 & 0 & 1 \\
\hline Journal of Higher Education Policy and Management; & 2003 - Present & 1 & 1 & 0 & 0 \\
\hline Teaching in Higher Education; & 2005 - Present & 9 & 7 & 3 & 6 \\
\hline European Journal of Higher Education & 2011 - Present & 0 & 2 & 1 & 0 \\
\hline Tertiary Education and Management & 1995 - Present & 0 & 1 & 0 & 0 \\
\hline Quality in Higher Education & 1995 - Present & 0 & 1 & 0 & 1 \\
\hline \multirow[t]{2}{*}{ Higher Education in Europe } & $1976-1995 ; 2005-2009$ & 0 & 0 & 1 & 0 \\
\hline & & 37 & 35 & 19 & 22 \\
\hline
\end{tabular}

Table 2. Presence of references to works of Gramsci, Wallerstein, Althusser, Adorno in main HER outlets. Data source: Scopus. Authors' elaboration.

Our analysis uncovered a modest presence of references to most known Marxist thinkers (from different generations and different national traditions). Why then, with such an underrepresentation of Marx's and Marxists reflection within HER, do we find its inclusion in the spectrum of theoretical tools useful, and why it may lead to the field's development? First, while HER is dominated by the naturalized opposition between the public and the private (Marginson 2016), Marx's critique proposes a political view on the ontology underlying research projects developed within HER (Marginson \& Yang 2021; Szadkowski 2019b). Second, Marx's critique enables the restoration of the significance of the production sphere (instead of the emphasis on the sphere of exchange - the market), and it also reveals the opposing material interests between academic workers and capital trying to subjugate this sector as a whole. The sphere of the political economy of higher education is also a place where we see a potential for substantial gains on the side of Marxist theory. While most of the Marxist accounts approach the sector with a ready-made theoretical framework that universalizes the industrial modes of value extraction and theoretically subsume the analysed sector under it, HER has a substantial insight into how the production in higher education operates. Third, while HER in diagnosing problems arising from capitalist structuring of the sector remains helpless in mobilizing the resistance towards these processes, often appealing to the conscience of the governments implementing problematic reform programs, Marxist critique is directly linked to a specific subject with the ability to take responsibility for carrying out the desired changes (Szadkowski \& Krzeski 2021). It, therefore, sees the research as a process transgressing the borders between the subject and the object, presenting it rather as a co-research through which resisting actors might co-articulate their agendas (Roggero 2011). Fourthly, if in HER the 
horizon of change is either fine-tuning and rationalizing the current direction of the sector's transformation (Slaughter \& Rhoades 2004), or developing projects to return to full public control (Newfield 2016), Marx's method is linked to a clearly defined alternative of going beyond the horizon of the capitalist status quo (Szadkowski 2019a; Szadkowski \& Krzeski 2019b). In this article, we will discuss Marx's critique with the reference to these four aspects, at the same time exploring the modest prospects for the development of Marxist reflection on higher education through an encounter with undertheoretized HER.

\section{Competing perspectives on capitalist transformations in HER}

The following section introduces two dominant perspectives within HER on the capitalist changes in higher education: academic capitalism and exceptionalism. Both of them are important insofar as they were developed to capture the functioning and transformation of the higher education sector in the conditions of globalized capitalism. For this reason, they are in natural competition with any Marxist theories in explaining the capitalist aspects of the activities within the sector.

\section{Academic capitalism}

Academic capitalism is both a subject of study and a specific theory, which, as Brendan Cantwell and Ilkka Kauppinen claim $(2014,6)$, offer a conceptual framework and methodological tools for dealing with the capitalist changes. According to the classic definition, academic capitalism: ,is institutional and professional market and market-like activities aimed at providing external funds" (Leslie \& Slaughter 1998, 8). On the one hand, market-like activities relate to institutions and academics competing for money from external resource providers (whether private or public); while market activities - strictly focused on profit (forprofit) activities, regardless of whether they are activities directly related to one of the basic missions of the university, or simply selling products on the campus or renting space. Underlying the classic concept of academic capitalism was the resource dependency theory (Pfeffer \& Salancik 1978) used to test whether higher education institutions were adapting to the new financial constraints brought about by the development of neoliberal austerity policies of the 1980s and 1990s. Slaughter and Rhoades $(2004,329)$ noted that the clear boundary between the public and private sectors has blurred while maintaining substantial public funding for market ventures and activities and market-like academic institutions and their staff. This manifested in the entry of the profit motive into activities of academic staff or privatization of research profits (staff becoming co-owners of spin-offs or capital venture companies independent from universities, where they undertook long-term research financed with public money), as well as publicizing losses.

Academic capitalism theorists accurately capture the transition from direct state control over higher education systems to state control mediated by market mechanisms (Leslie \& Slaughter 1998, 228). Their perspective, however, might be problematic on two accounts. The first one is theoretical. It refers to the assumption that boundaries between the private and the public, blurred by academic capitalism, can be re-established (Slaughter \& Rhoades 2004, 56-57). When diagnosing the new form of exercising power, the authors representing this perspective concluded that the answers to the growing problems should be sought in returning to the public and strengthening state power within the sector. The second is related to how academic capitalism is applied. As Garry Rhoades pointed out, "academic capitalism, like capitalism in general, is concerned with power rooted in social relations of production. It concerns not only 'enhanced managerial ability', but also efforts to expand managerial control and collective struggles against these efforts" (2014: 114). The representatives of this perspective, at least in 
its classical form, were fully aware of it. However, with the development of this perspective in HER, a significant paradox emerged, researchers often overlooked its critical potential, using works on academic capitalism more like ,implementation manuals” (Slaughter 2014: viii; see. Sigahi \& Saltorato 2020).

\section{Exceptionalism}

There is a group of less formalized perspectives to which we refer under a common label of exceptionalism. No matter that elements of similar views might be found in different theories and disciplines, we focus on how it manifests in HER. What is exceptionalism in thinking about higher education and its economic transformation? To put it shortly, it is a theoretical and political position that assumes that due to its specificity (internal modes of articulation), higher education as an academic enterprise cannot be reduced to mere economic activities. Therefore, according to this line of argumentation, speaking of per se capitalist transformation of the sector, presence of capital in Marxian sense of the term, or any form of subsumption of academic labour under capital (Szadkowski 2016) is futile. This is because higher education cannot be reduced to its mere economic functions.

The reasons for that are multifarious, yet, three core components stand out. First, higher education is understood as the public good or the common good (Tilak 2009; Marginson 2016; Locatelli 2019), therefore it is endowed with specific political traits of the national or global agendas that go beyond the mere economic benefits. They range from preserving the national or cultural identity, contribution to the cultural development of the regions, solutions to the most severe national health problems. They are considered more important than the economic market-mediated competition between the higher education agents. Moreover, they often overtake its position on the list of national priorities in the sphere of higher education policy. Second, higher education is a node in status distribution networks, both nationally and globally (Blackmore 2016; Blackmore \& Kandiko 2011). Moreover, the institutions that form its national and global system, and individual scholars are driven by competition for recognition. The prestige-seeking seems to be a more important motivation in higher education and science, than the search for profits, and, as the global university ranking race indicates, universities are ready to pursue even economically irrational strategies to get higher ranks or positions (Munch 2014). All because status and prestige historically are important value signalling devices within the sector (Reitz 2017). Third, knowledge, a core resource and output of higher education, in its ontological form resists the attempts of privatization (Szadkowski \& Krzeski 2019b). Nobody can know only as an individual. Knowledge requires sharing and dialogue. Therefore, it assumes a different ontology than privatized knowledge commodities, protected by intellectual property rights (Tyfield 2008).

Those are the three pillars on which the ideal type of exceptionalism position in higher education stands. While there are many representatives that to different degrees follow exceptionalist line of thinking about higher education and its potential capitalist subordination (see. Munch 2014), integrating into their research agendas or policy proposals various components of the exceptionalism, some of the higher education researchers stand out of the crowd. One of the main proponents of this line of reasoning is Simon Marginson, who for the last 30 years build a coherent proposal in the culturally specific political economy of higher education (Marginson 2004; 2010; 2013; 2016) and formulated a claim of the specificity of the sector that restrains it from undergoing a fully capitalist transformation (Marginson 2013). Moreover, it is worth noting that academic capitalism and exceptionalism are not mutually exclusive. In recent years we could rather observe an ongoing synthesis of the two theoretical 
perspectives that we discussed here in their efforts to explain academic capitalism (or its seeming impossibility) (Munch 2014; Rietz 2017; Slaughter \& Taylor 2016; Marginson 2016).

Having introduced the two dominant theoretical perspectives on the capitalist transformation of $\mathrm{HE}$ and assumptions that underpin them, we will briefly discuss Marx's notion of critique before proceeding to the possibility of dialogue between HER and Marxism.

\section{Marx's concept of critique}

Karl Marx never left us a universal blueprint that can be applied to contemporary higher education, yet he left his method (Rikowski 2004; Szadkowski \& Krzeski 2019a). A specific mode of inquiry and intervention into the reality of capitalist society and economy to which we refer here as critique. Critique itself is not estranged to HER (Williams 2012). We are often presented with critical perspectives on inner university life - from studying the curriculum and inquiry about the academic profession to global university rankings and geopolitics of higher education. Nonetheless, discerning a common thread that ties them is not easy. What seems common is a shared assumption that the objectified reality of the sector hides from our view inbuilt inequalities and power relations that are constitutive of the sector. The work of critique is therefore to bring those conditions to the fore (Marx 1982). Once they are exposed and turned into the object of knowledge, it becomes possible to reflect on and act towards their elimination. The extent to which such actions are justified differs greatly across particular studies and depends on a theoretical and political position of a given author. Although Marx's critique shares some basic principles with how critique functions within HER it retains its specific, integral meaning.

First, Marx's critique treats market relations as the level of appearance as from its perspective we see merely individuals who enter in agreements with one another on an equal basis. In turn, it is only through the sphere of production that one can understand the true meaning of exploitation in a given society, i.e., the capture and appropriation of the products of someone else's labour. Second, capitalism has a distinct form of organizing exploitation. Here, the relation between labour and capital is presented in a conflictual manner. This is because the capital drive to self-valorisation depends on overriding itself on labour's creative potential and making it subservient to its ends. Therefore, the ultimate goal of Marx's critique is to offer the means to severe the relation between capital and labour and not turn it simply into an object of knowledge. When reformulated in the context of higher education, the Marxian task of critique can be explained as an inquiry into the academic labour resistance towards its relation to capital (Roggero 2011). From this, stems two important consequences. First, one has to account for capital's presence within the university sector. Second, treat its presence, not as yet another constituency of higher education, but as a key actor responsible for the transformation of the sector's activity. In other words, the basic assumption of Marx's critique in the context of higher education can be formulated as follows: when capital enters the reality of the sector it recognizes its internal logic and seeks the means to profit from it (Szadkowski 2016), however, once it established itself it commences a process of sector's structurization (Hall 2018). Hence, critique is an intervention in this process. An intervention that as its goal has emancipation from academic labour (Winn 2015). We will elaborate further on specific tools that can be utilised in this task.

The Marxian notion of critique can be better grasped through the integrity of the three moments of critique (Rikowski 2004) or "In-Against-Beyond" figure (Szadkowski \& Krzeski 2019a). Marx and Engels defined it as "the real movement which abolishes the present state of things. 
The conditions of this movement result from the premises now in existence" (Marx \& Engels $1968,60)$. In light of this quote, one can integrate different moments of critique. The first one, "In", relates to uncovering inner contradictions of capitalist reality. We refer to this moment as a critique of political economy. The second one, "against", accounts for the antagonistic nature of relations within capitalism. Finally, the third one, "beyond", points towards a tangible alternative to the current predicament. While such triple structure might, at first sight, seem like a simple dialectical syllogism and indeed there is a dialectical tension that ties the moments with each other, it has to be emphasized that from a purely methodological point of view, there is no primacy of one moment of analysis over the others. There is no teleology. Rather they can be imagined as forming a circle that one needs to break with. For example, in researching conflictual higher education reality, one may take the eruptions of students' outrage ("against") as a point of departure and investigate both the aspects of the political economy of the sector that they shed the light on ("in") and the pathways beyond the current predicament that they open up and cry for ("beyond"). Therefore, the individual moments of critique necessarily refer to each other and form a methodological virtuous circle.

How we can translate Marx concept of critique into a more tangible, yet still general research program for higher education research?

\section{What Marx has to offer to HER?}

From what premise did Marx initiate critique and how it can be understood in the context of higher education? Before outlining his critical project in Grundrisse (1973) Marx investigated assumptions made by his theoretical adversaries and presented his premises. In this sense, Marx practised political ontology, i.e. a type of reflection that uncovers hidden and ideological presuppositions while establishing ground on which critique can operate (Szadkowski and Krzeski 2019b). Marx contrasted two different conceptions of the individual - isolated individual vs social individual. Using either of them as a premise has radically different consequences for understanding social worlds in general and the production sphere in particular. As he states, "Production by an isolated individual outside society (...) is as much of an absurdity as is the development of language without individuals living together and talking to each other" (Marx 1973, 84). Producing individuals in science and higher education constitutes a natural point of departure for any analysis of the sector's activities. However, according to Marx's ontological assumption, to remain on the individual level does not only mean to fail to see a multitude of social relations and networks of cooperation that forms a basis on which individuals may operate. Something much more important is at stake. Surrendering to the individualistic perspective on higher education is tantamount to surrendering to the logic that allows capital to function in the sector in the first place. As its presence is impossible without overriding itself on social productivity and transforming it into individual formmeasurable, commensurable and, thus, ready for valorisation (Szadkowski 2019b). Nonetheless, this process is far from complete as collective practice poses continuous challenges when attempts are made for its individualization (Szadkowski 2019a). For these reasons, contradictions between the collective nature of academic endeavour and their individual form have to be traced.

The tension between the social individual and isolated individual constitutes a premise from which critique can proceed. In this sense, it precedes the three moments of critique. First, "In" has to be introduced as a moment of critique of the political economy of higher education. Here, Marx's fundamental insight comes to the fore, namely that when capital subjugates new areas and sectors to its rule, it is forced to embed itself in the internal structure of the encountered 
sector (Marx 1981). Thus, it has to exploit practices and forms of organization already present within the sector. For instance, if higher education function as a prestige or status economy, capital presence does not nullify it and impose a simple form of money-driven competition (Munch 2014). Rather, it inscribes itself into this logic. The presence of commercial entities boils down exactly to the use of the valorisation methods existing in the university sector and subordinating them to self-valorisation of capital (Chen et al. 2019). The role of global university rankings or control of scholarly communication channels by commercial publishers and commercial data providers can serve as an example of this process (Szadkowski 2016). To this extent, the task of critique is to follow those developments and indicate the consequences they have on academic labour. In other words, the "In" moment of critique accounts for inquiry into capital's presence in the sector from the perspective of academic labour.

Second, "Against", as a moment of critique accounts for the necessity to abolish present relations within the university sector through praxis. If the work of the critique of political economy renders visible the contradictions within which the present system can be thrown off balance, making the status quo vulnerable, it is only through taking the antagonistic stance that one can cut the link between academic labour and capital (Szadkowski 2016). In that sense, Marx's notion of critique rejects any form of necessity in which knowledge gained about capital presence automatically translates itself into political action. For this reason, critique does not simply embody itself in various student and academic protests, but rather follow them and trace the contradictions which were exposed in the course of struggles. It strives to establish a relation with movements, one in which critique can fuel indignation and protect the movement from cooptation and institutionalisation (Szadkowski \& Krzeski 2021). Instead of developing a moral high ground from which critics can preach (Neary 2016), critique utilizes a method of coresearch (Roggero 2011). It is through the method of co-research that a productive link between two moments of critique is established. On the one hand, "against" gain insight acquired from the "in" moment of critique and on the other, "against" draws "in" attention to new spaces of capitalist structurization of universities.

Third, "Beyond" refers to the problem of alternative to the current form of organization of social relations within the university sector (Szadkowski \& Krzeski 2019b). In that sense, the work of critique does not equate with destruction, but through severing capitalist relation it serves the purpose of recreating university on different grounds. Hence, the question about the alternative is an integral part of Marx's critique. This alternative is by no means an abstract and utopian idea, but it shines through the capitalist structuration of higher education and the activists struggles against it. It may bring an end to the current predicament of higher education and contribute to its emancipation. This promise is the common (Szadkowski 2019a). The universities based on the logic of the common are already emerging in different national contexts (Wright et al. 2011; Pusey 2017). First and foremost, they make their resources common, especially when it comes to knowledge and teaching resources that may benefit both the internal community of learners and the broader societal plane. Second, they aim to develop schemes of self-management, struggling to be self-sustaining and being able to determine their areas of activity. Finally, they subject the decisions to procedures of democratic participation, whether that be a democratic plenum open to all academics and citizens of a given city or other inclusive structures that allow for going beyond a rigid academic identity and open up the institution to its wider surroundings. The common-driven universities are inclusive institutions that aim at the global transformation of social relations. To this extent, the task of critique is to help create such conditions which favour the expansion of the common.

\section{Establishing the grounds for the dialogue between Marxism and HER}


In the course of the argument, it became clear that the full reconciliation between Marxism and HER is hardly possible. Nonetheless, the encounter between the two perspectives can still be productive and enriching for both. In the concluding remarks, we will indicate on what grounds such an encounter may occur and what is to be theoretically gained from encouraging representatives of both fields to engage in a further discussion.

First, both academic capitalism and exceptionalism recognize the problem of hybridization of public-private orders, which is a consequence of exposing the university sector to the market forces and the role the state play in this process (Slaughter \& Rhoades 2004; Marginson 2016). In face of this blur, they advocate for strengthening the public character of higher education sectors and a more interventionist approach from the state (Newfield 2016; Cantwell \& Kaupinnen 2014). In turn, the Marxian approach in a form of political ontology not only offers tools for discerning the private-public order but through their critique, put forward an alternative order. On the one hand, it interrogates ontological assumptions about the primacy of the individual, underpinning market presence in science and higher education. On the other, it examines assumptions regarding totality that encompasses individual parts, which underpins the coordinating role of the state vis-a-vis the university sector. In concequence, Marxian political ontology based on the common rejects the hegemony of those two ontological models, not only at the theoretical level but also in their material basis. Engaging with HER can help Marxism further ground empirically and develop its understanding of how the common is materially embedded within the past and contemporary practices of teaching/learning and collective knowledge production.

As for the political economy of the sector, both academic capitalism and exceptionalism use market and quasi-market terms to conceptualize capitalist relations. Thus, they locate the core of capitalist transformations in the sphere of exchange and the occurrence of the commodity form, rather than in the sphere of production with its relations of exploitation. Additionally, exceptionalists such as Simon Marginson (2013) go even a step further, completely negating the possibility of capital in the Marxian sense in the sphere of production in higher education (Marginson 2016) ${ }^{3}$. In this way, not only do they ignore the processes of capital penetration into the reality of higher education, but also struggle to formulate alternative solutions to the problems it generates. Some higher education researchers show that private companies are increasingly important to the functioning of the systems as a whole, as well as they point at an increasingly worrying development of platform capitalism in higher education (Komljenovic 2021). In the same context, attention is often paid to the growing dominance of publishing oligopolies (Lariviere et. al 2015) or the spread of capitalist online learning platforms (Williamson 2020), the importance of which has increased during the pandemic. While researchers in the field increasingly discuss these processes through critical perspectives, they do not come up with solutions other than ones from within the horizons of the capitalist imaginary. At this point, the Marxist-inspired critique allows us to break this practical and theoretical deadlock. It enables a more systemic approach to the problem of economic relations,

\footnotetext{
${ }^{3}$ While question of how Marxian notion of capital manifests in higher education (globally and nationally) remain open, dropping the Marxian concept once and for all seems like a hasty move. Difference between individual institutions becoming fully capitalist enterprises "producing" higher education "for profit" and the systemic productivity of academic labour is here of crucial importance (see. Szadkowski 2019b). While we agree that the direct applicability of the Marxian concept of capital to the analysis of the contemporary public university in the global status economy is limited, we cannot agree that such observation is enough to claim that capital in a Marxian sense is nowhere to be seen in higher education. As system is not just the sum of individual institutions, relations between the capitalist actors and actors within the field do not necessarily have to be established on the institutional grounds.
} 
going beyond a single institution as a unit of analysis, revealing further problems for exploration. In turn, through this encounter Marxism has the opportunity to challenge and question its attachment to the theoretical patterns established in relation with industrial mode of capitalism and keep up with the ever-evolving capitalist mode of production.

One of the great shortcomings of the theory of academic capitalism is its development without reference to specific subjects harmed by the implementation of capitalist relations in the sector (Pérez \& Pasque 2013; Rhoades 2014; Jessop 2017). In turn, it is hard to find any conceptualization of the subject of change in the exceptionalist trend. In both theoretical tendencies, the addressees of the postulates concerning the necessary changes in the sector are rather governments and the management of academic institutions. Marxist critique, in connection with a concrete subject fighting for emancipation from capitalism (and academic capitalism in particular), not only allows this trend of reflection to become part of social alliances but can contribute to expanding the autonomy of the protesting social forces (Rikowski 2004; Roggero 2011; Szadkowski \& Krzeski 2019a). First, Marxist perspective places the transformations of the sector in a much broader context of socio-economic struggles against the capitalist subsumption of labour (Szadkowski 2016). To be solved, the issues affecting academics and students must become part of a larger protest movement involving all social forces working to change the status quo. Second, the dialogical relationship established between HER researchers and current social struggles feeds the Marxist-inspired HER with the most current topics and allows researchers to engage in reformulating the ideas dominant in movements into viable schemes for the operation and reorganization of universities (Szadkowski \& Krzeski 2021).

Finally, lacking different ontological ground from the public-private divide, focusing on market presence and not perceiving academic labour in antagonistic categories might lead to an image of the passive sector. From this perspective, a risk arises that the higher education sector will turn into an object rather than a subject of its self-transformation as both academic capitalism and exceptionalism cannot account for what we refer to as the "beyond" moment of critique. The importance of the Marxian perspective for the challenges faced by higher education in the twenty-first century is, therefore, nothing else than the hope to break with the dependency. As it is subordinating the process of knowledge accumulation not to profit, but to the fulfilment of collective needs in constantly expanding conditions. In turn, HER reveals the conditions that have to be taken into account when thinking about the alternative beyond the single HEI, as it unveils the glonacal nexus of dependency in which contemporary higher education is embedded.

In this paper, we have shown that although Marx's critical insight is largely absent from HER, it is capable of contributing to the further development of the field. In turn, the key differences between Marxism and the two dominant models which were highlighted in the argument were exposed as a focal point around which the encounter between Marxism and HER might occur. This encounter is by no means one-sided, in a sense that only Marxism can offer the means to transcend limitations inherent to HER. On the contrary, Marxism as an open theory can itself develop only insofar as it can enter into a productive dialogue with other perspectives. This is because only in this way it is able to challenge its own assumptions. This is the precise meaning of mutually productive dialogue between Marxism and HER that we were pursuing in the course of the argument. While discussing the limitations of the theory of academic capitalism and exceptionalism, we have indicated those places where Marx's critique is able not only to lead the field to new areas but also to realize the limitations inherent in most of HER, resulting from the naturalization of a specific, unproductive ontological binary of the public and the 
private. Moreover, we have pointed out the fact that the use of the conceptualization of capitalist changes in the sector is politically ineffective and is not able to effectively support the solution of most of the diagnosed problems resulting from academic capitalism. In addition, we made it clear that by approaching an area that is insufficiently explored on their grounds, Marxist theories can develop a set of intuitions already contained in Marx's oeuvre (1981) by tracing how capital instrumentalises the internal articulation of the system of value signalling in the field of higher education - prestige - to systematically subordinate academic labour (Szadkowski 2016; 2019b).

Although we are not convinced of the possibility of an imminent synthesis of HER and Marx's critique, we believe that there is room for research programs inspired by Marx's works in research on the structural determinants of the functioning of higher education, as well as in the study of the consequences of capitalist transformations that are ongoing in the sector. To this extent, Marx and his method retain their relevance for higher education research. 


\section{References}

Althusser, L. (1971). Ideology and Ideological State Apparatuses. (B. Brewster, Trans.). In L. Althusser, Lenin and Philosophy and Other Essays (pp. 127-186). New York: Monthly Review Press.

Arboledas-Lérida, L. (2020). Capital and the Scientific Endeavour. An Appraisal of Some Marxist Contributions to the Debate on the Commodification of Science. Critique, 48(4), 321-367.

Ashwin, P. (2012) How often are theories developed through empirical research into higher education?, Studies in Higher Education, 37:8, 941-955.

Bernal, J. D. (1939). The Social Function of Science. London: FF.

Blackmore, P. \& Kandiko, C. B. (2011). Motivation in academic life: a prestige economy. Research in Post-Compulsory Education, 16:4, 399-411.

Blackmore, P. (2016). Prestige in Academic Life: Excellence and Exclusion. London: Routledge.

Bligh, B. \& M. Flood. (2017). Activity theory in empirical higher education research: choices, uses and values. Tertiary Education and Management, 23(2): 125-152, 10.1080/13583883.2017.1284258

Bowles, S., \& Gintis, H. (1976). Schooling in capitalist America. New York: Basic.

Cantwell, B. (2020). Explanatory accounts in international and comparative higher education research. Higher Education Quaterly 74(2): 149-161, https://doi.org/10.1111/hequ.12246

Cantwell, B. \& Kauppinen, I. (2014). Academic Capitalism in the Age of Globalization. Baltimore: JHU Presss.

Chen, G., A. Posada \& L. Chan. 2019. Vertical Integration in Academic Publishing. Implications for Knowledge Inequality. Toronto: Open Edition Press.

Cleaver, H. (2004). On Schoolwork and the Struggle Against it. Treason Press: Canaberra.

Clegg, S. (2012). Conceptualising higher education research and/or academic development as 'fields': a critical analysis, Higher Education Research \& Development, 31:5, 667-678.

Collins, H., Glover, H. \& Myers, F. (2020). Behind the digital curtain: a study of academic identities, liminalities and labour market adaptations for the 'Uber-isation' of HE. Teaching in Higher Education.

Daenekindt, S., \& Huisman, J. (2020). Mapping the scattered field of research on higher education. A correlated topic model of 17,000 articles, 1991-2018. Higher Education, 117.

Fraser, B. (2009). The 'kind of problem cities pose': Jane Jacobs at the intersection of philosophy, pedagogy, and urban theory. Teaching in Higher Education, 14:3, 265-276.

Grealy, L. \& Laurie, T. (2017). Higher degree research by numbers: beyond the critiques of neo-liberalism. Higher Education Research \& Development, 36:3, 458-471.

Gulli, B. (2009). Knowledge Production and the Superexploitation of Contingent Academic Labor. Workplace: Journal for Academic Labor, 16, 1-30.

Hall, R. (2018). The Alienated Academic: The struggle for autonomy inside the university. Dordrecht: Springer.

Harvie, D. (2005). All Labour Produces Value For Capital And We All Struggle Against Value. The Commoner, 10, 132-171.

Hessen, B. (2009). The Social and Economic Roots of Newton's Principia. In G. Freudenthal and P. McLaughlin (eds.), The Social and Economic Roots of the Scientific Revolution. Berlin: Spirnger.

Horta, H., \& Jung, J. (2014). Higher education research in Asia: An archipelago, two continents or merely atomization?. Higher Education, 68(1), 117-134. 
Jessop, B. (2017). On academic capitalism. Critical Policy Studies, Advance online publication, 104-109.

John G. Fox \& Pauline O’Maley. (2017). Adorno in the classroom. Studies in Higher Education.

Komljenovic, J. (2020) The future of value in digitalised higher education: why data privacy should not be our biggest concern. High Educ.

Larivière, V., Haustein, S., \& Mongeon, P. (2015). The oligopoly of academic publishers in the digital era. PloS one, 10(6).

Locatelli, R. (2019). Reframing Education as a Public and Common Good. Basingstoke: Palgrave.

Macfarlane, B. (2012). The higher education research archipelago. Higher Education Research \& Development, 31(1), 129-131.

Macfarlane, B., \& Grant, B. (2012) The growth of higher education studies: from forerunners to pathtakers, Higher Education Research \& Development, 31(5), 621-624.

Marginson, S. (1998). Value creation in the production of services: A note on Marx. Cambridge Journal of Economics, 22, 573-585.

Marginson, S. (2004). A revised Marxist political economy of national education markets. Policy Futures in Education, 2(3-4), 439-453.

Marginson, S. (2013). The impossibility of capitalist markets in higher education. Journal of Education Policy, 28(3), 353-370.

Marginson, S. (2016). The higher education and the common good. Sydney: Melbourne University Press.

Marginson, S., \& Yang, L. (2021). Individual and collective outcomes of higher education: a comparison of Anglo-American and Chinese approaches. Globalisation, Societies and Education, 1-31.

Marx, K. (1973). Grundrisse. London: Penguin Books.

Marx, K. (1982). Capital. A Critique of Political Economy. London-New York: Penguin Books and New Left Review.

Marx, K., and F. Engels. (1968). The German Ideology. Moscow: Progress Publishers.

Moten, F., \& Harney, S. (1999). The academic speed-up. Workplace: A Journal for Academic Labor, (4).

Munch, R. (2014). Academic Capitalism. London: Routledge.

Neary, M. (2016). Student as Producer: The Struggle for the Idea of the University. Other Education: The Journal of Educational Alternatives, 5(1), 89-94.

Newfield, C. (2016). The great mistake: How we wrecked public universities and how we can fix them. Baltimore: Johns Hopkins University Press.

Pérez, M. S., \& Pasque, P. A. (2013). Challenging the neoliberal climate in academia from mentoring perspectives: critical reflections from our future selves. Cultural StudiesCritical Methodologies, 13(6), 474-480.

Pfeffer, J. \& Salancik, G. R. (1978) The External Control of Organizations: A Resource Dependence Perspective. University of Illinois.

Reitz, T. (2017) Academic hierarchies in neo-feudal capitalism: how status competition processes trust and facilitates the appropriation of knowledge. High Educ 73, 871-886.

Rhoades, G. (2014). Extending academic capitalism by foregrounding academic labor. In, Academic capitalism in the age of globalization, 113-134.

Rikap, C. (2017). The differentiated Market-University structural differences among University's commodification processes. In Theory and Method in Higher Education Research. Emerald Publishing Limited.

Rikap, C., \& Harari-Kermadec, H. (2020). The direct subordination of universities to the accumulation of capital. Capital \& Class, 44(3), 371-400. 
Rikowski, G. (1997). Scorched Earth. Prelude to Rebuilding Marxist Educational Theory. British Journal of Sociology of Education, 18(4), 551-574.

Rikowski, G. (2004). Marx and the Education of the Future. Policy Futures in Education, 2(3/4), 565-577.

Roggero G. (2011). The Production of Living Knowledge. (E. Brophy, Trans.). Philadelphia: Temple University Press.

Santos, J. M., \& Horta, H. (2018). The research agenda setting of higher education researchers. Higher Education, 76(4): 649-668.

Sigahi, T.F.A.C., Saltorato, P. (2020). Academic capitalism: distinguishing without disjoining through classification schemes. Higher Education 80: 95-117.

Slaughter, S. (2001). Problems in comparative higher education: Political economy, political sociology and postmodernism. Higher Education, 41(4), 389-412.

Slaughter, S. (2014). Forward: Academic capitalism in the age of globalization, In, Academic capitalism in the age of globalization.

Slaughter, S. \& Leslie, L. (1998). Academic capitalism. Baltimore: JHU Press.

Slaughter, S. \& Taylor, B. J. (eds.) (2016). Higher Education, Stratification, and Workforce Development. Dordrecht: Springer.

Slaughter, S., \& Rhoades, G. (2004). Academic capitalism in the new economy. Challenges and choices. American Academic, 1(1), 37-59.

Sutton, P. (2015). A paradoxical academic identity: fate, utopia and critical hope Teaching in Higher Education, 20:1, 37-47.

Sutton, P. (2017). Lost souls? The demoralization of academic labour in the measured university. Higher Education Research \& Development, 36:3, 625-636.

Szadkowski, K. (2016). Towards an orthodox Marxian reading of subsumption (s) of academic labour under capital. Workplace: A Journal for Academic Labor, (28).

Szadkowski, K. (2019a). The common in higher education: a conceptual approach. Higher Education, 78(2), 241-255.

Szadkowski, K. (2019b). An Autonomist Marxist Perspective on Productive and Un-productive Academic Labour. tripleC 17(1): 111-131.

Szadkowski, K. \& J. Krzeski. (2019a). In, against, and beyond: a Marxist critique for higher education in crisis. Social Epistemology, 33(6), 463-476.

Szadkowski, K. \& J. Krzeski. (2019b). Political Ontologies of the Future University: Individual, Public, Common. Philosophy and Theory in Higher Education, 1(3), 29-49.

Szadkowski, K. \& J. Krzeski. (2021). The future is always-already now: Instituent praxis and the activist university. Policy Futures in Education.

Tyfield, D. (2008) Enabling TRIPs: The pharma-biotech-university patent coalition. Review of International Political Economy 15(1): 535-566.

Teichler, U. (1996). Comparative higher education: Potentials and limits. Higher education, $32(4), 431-465$.

Teichler, U. (2015). Higher education research in Europe. In The European higher education area (pp. 815-847). Springer, Cham.

Tight, M. (2003). Researching Higher Education. Open University Press: .

Tight, M. (2004). Research into higher education: An a-theoretical community of practice?. Higher Education Research \& Development, 23(4), 395-411.

Tight, M. (2013). Discipline and methodology in higher education research, Higher Education Research \& Development, 32:1, 136-151.

Tight, M. (2014). Discipline and theory in higher education research. Research Papers in Education, 29:1, 93-110.

Tight, M. (2015). Theory development and application in higher education research: Tribes and territories. Higher Education Policy, 28(3), 277-293. 
Tight, M. (2018). Systematic reviews and meta-analyses of higher education research. European Journal of Higher Education.

Tilak, J. B. G. (2009). Private sector in higher education: A few stylized facts. Social Change, $39(1), 1-28$.

Trowler, V. (2015). Negotiating contestations and 'chaotic conceptions': Engaging 'nontraditional'students in higher education. Higher Education Quarterly, 69(3), 295-310.

Walker, J. (2009). Time as the fourth dimension in the globalization of higher education. The Journal of Higher Education, 80(5), 483-509.

Welsh, J. (2021). Tolling academics: rent-seeking and gatekeeping in the university space. Capital \& Class, 45(1), 93-121.

Welsh, J. (2020). Dispossessing academics: The shift to 'appropriation' in the governing of academic life. European Journal of Social Theory, 23(3), 350-369.

Winn, J. (2015). Writing about academic labour. Workplace: A Journal for Academic Labor, (25). Williams, J. J. (2012). Deconstructing Academe. The Chronicle of Higher Education, 58 (25).

Wright, S., D. Greenwood, and R. Boden. 2011. Report on A Field Visit to Mondragón University: A Cooperative Experience/experiment. Learning and Teaching, 4(3): 38-56, 10.3167/latiss.2011.040304.

Krystian Szadkowski, $\mathrm{PhD}$, is a researcher at the Scholarly Communication Research Group of Adam Mickiewicz University in Poznan. His interests cover political economy and trans- formations of higher education systems in Central Eastern Europe, as well as the issues of the public and the common in higher education. He worked as a researcher for Education International (Brussels, Belgium) and as a consultant in policy projects funded by the Polish Ministry of Science and Higher Education. He was a visiting researcher at the Centre for Global Higher Education, both at the Institute of Education, University College London (in 2018) and at the University of Oxford (in 2020). His interests cover political ontology, political economy of higher education, critical university studies, higher education research.

Jakub Krzeski, PhD and assistant professor at the Institute of Philosophy, Nicolaus Copernicus University and a researcher at the Scholarly Communication Research Group of Adam Mickiewicz University in Poznan. His interests cover primarily the problem of quantification and measurement of higher education and science sectors, which he approaches from the perspective of critical theory. He is preparing his doctoral dissertation in which he researches how conflict around different orders of worth in the academic disciplines shapes and impacts research evaluation systems. He is currently carrying out a research project 'Struggles over measures: The case study of research eval- uation in biology in Poland in the 1990-2020 period' funded by the Polish National Science Centre. 